\title{
Health care resource use and costs for Crohn's disease before and after infliximab therapy
}

\author{
Dustin E Loomes MD, Christopher Teshima MD, Philip Jacobs PhD, Richard Fedorak MD
}

DE Loomes, C Teshima, P Jacobs, R Fedorak. Health care resource use and costs for Crohn's disease before and after infliximab therapy. Can J Gastroenterol 2011;25(9):497-502.

BACKGROUND: Infliximab therapy in patients with Crohn's disease decreases resource use; however, the overall impact on health-related expenditures is unclear, especially beyond one year of study.

METHODS: A retrospective analysis of economic data one and two years before and after infliximab therapy was performed using patients who served as their own controls. Total health care resource use and direct health care costs were compared for patients with or without fistulae. RESULTS: Patients with one $(n=66)$ and two $(n=39)$ years of economic data before and after infliximab treatment had their resource use and direct health care costs estimated. In the year following initiation of infliximab therapy, there were significant decreases in health care use, reflected in total hospital days (495 to $155[\mathrm{P}<0.05])$, inpatient colonoscopies (46 to $24[\mathrm{P}<0.05]$ ), outpatient colonoscopies ( 58 to $33[\mathrm{P}<0.05])$ and major surgeries $(10$ to $2[\mathrm{P}<0.05])$. Direct health care costs of inpatient costs for luminal $(-\$ 1,747[\mathrm{P}<0.05])$ and fistulizing disease $(-\$ 2,530[\mathrm{P}<0.05])$, major surgeries $(-\$ 1240$ $[\mathrm{P}<0.05])$ and outpatient colonoscopies $(-\$ 184[\mathrm{P}<0.05])$ were also significantly reduced before and after infliximab therapy. Total direct health care costs, including the drug cost of infliximab, increased $(\$ 21,416[\mathrm{P}<0.05])$. In general, the trends in health care costs analyzed over four consecutive years paralleled the two consecutive-year analysis. CONCLUSIONS: Infliximab therapy in patients with Crohn's disease resulted in a significant decrease in both resource use and health care costs, but an increase in total direct health care costs once the cost of infliximab was added.

Key Words: Crohn's disease; Economic analysis; Health care cost; Health policy; Inflammatory bowel disease; Infliximab

$\mathrm{O}^{\prime}$ ver the past decade, the treatment of Crohn's disease has changed remarkably, perhaps most notably with the introduction of antitumour necrosis factor monoclonal antibodies, the first of which was infliximab. Infliximab is approved for the treatment of moderate to severe luminal and fistulizing Crohn's disease that is refractory to standard therapy, which includes corticosteroid and immunosuppressive medications (1). Although clinical trials have demonstrated the efficacy of infliximab for both induction $(2,3)$ and maintenance $(4,5)$ of remission, global availability remains restricted due to its cost (6).

Crohn's disease, however, is associated with considerable economic costs. Early age of onset, high morbidity, slightly reduced to near normal life expectancy and higher prevalence in industrialized first-world nations (with an estimated prevalence of 234 per 100,000 persons in Canada [7]) contribute to both high indirect costs (8) and direct costs (9). Furthermore, the top 7\% of patients with Crohn's disease are responsible for $50 \%$ of the total direct costs $(10)$, the majority of which are associated with hospitalizations and surgeries $(11,12)$.

Several studies have demonstrated that infliximab decreases resource use (13-17) and, for some patients, infliximab may reduce health-related expenditures (13). However, some analyses have

\section{L'utilisation et le coût des ressources de santé pour la maladie de Crohn avant et après une thérapie à l'infliximab}

HISTORIQUE : La thérapie à l'infliximabchez les patients atteints de la maladie de Crohn réduit l'utilisation des ressources. Cependant, on n'en connaît pas les répercussions globales sur les dépenses liées à la santé, notamment après plus d'un an d'étude.

MÉTHODOLOGIE : Les chercheurs ont mené une analyse rétrospective des données économiques un et deux ans avant et après une thérapie à l'infliximab auprès de patients qui étaient leurs propres sujets témoins. Ils ont comparé l'utilisation totale des ressources de santé et les coûts directs de santé chez les patients ayant ou non des fistules.

RÉSULTATS : Les patients pour qui on connaissait les données économiques sur un an $(n=66)$ et deux ans $(n=39)$ avant et après un traitement à l'infliximab ont fait évaluer leur utilisation des ressources et les coûts directs de santé. Pendant l'année suivant l'initiation de la thérapie à l'infliximab, on constatait une diminution significative de l'utilisation des soins de santé, reflétée par le total des jours d'hospitalisation (passant de 495 à $155[\mathrm{P}<0,05]$ ), les coloscopies chez les patients hospitalisés (de 46 à $24[\mathrm{P}<0,05])$, les coloscopies chez les patients en consultations externes (de 58 à $33[\mathrm{P}<0,05])$ et les opérations majeures (de dix à deux $[\mathrm{P}<0,05])$. Les coûts de santé directs des patients hospitalisés à l'égard des maladies d'origine luminale $(-1747 \$[\mathrm{P}<0,05])$ et des maladies fistulisantes $\left(\begin{array}{ll}-2 & 530 \$\end{array}\right.$ $[\mathrm{P}<0,05])$, des chirurgies majeures $(-1240 \$[\mathrm{P}<0,05])$ et les coloscopies chez les patients en consultations externes $(-184 \$[\mathrm{P}<0,05])$ diminuaient aussi considérablement avant et après une thérapie à l'infliximab. Toutefois, le total des coûts directs de santé, y compris le coût de l'infliximab, augmentait $(21416 \$[P<0,05])$. En général, les tendances des coûts de santé analysés pendant quatre années consécutives étaient similaires à ceux de l'analyse sur deux années consécutives.

CONCLUSIONS : La thérapie à l'infliximab chez les patients atteints de la maladie de Crohn assurait une diminution significative tant de l'utilisation des ressources que des coûts de santé, mais une augmentation du total des coûts directs de santé lorsqu'on ajoute le coût de l'infliximab.

suggested that infliximab therapy may actually increase total costs overall (17), and perhaps more so in those who lose response to infliximab (18). Additionally, practice patterns with regard to infliximab use have changed over the past decade, due in part to the acceptance of maintenance dosing, widespread adoption of immunosuppressive medications that enhance the efficacy and durability of infliximab therapy, and a shift toward outpatient care (19).

Therefore, the objective of the present study was to examine the economic and resource use benefits of infliximab therapy for the first time in patients with Crohn's disease up to two years postinfusion therapy using patients who served as their own controls.

\section{METHODS}

A retrospective analysis of all patients with Crohn's disease treated with infliximab at the Zeidler Gastrointestinal Health Centre, University of Alberta Hospital (Edmonton, Alberta), between September 2000 and August 2007, was conducted. All patients with Crohn's disease who resided within the Capital Health Region for at least one year before and one year following the initiation of infliximab therapy were identified to ensure health care resource use was captured within the

\section{Division of Gastroenterology, University of Alberta, Edmonton, Alberta}

Correspondence: Dr Dustin E Loomes, Division of Gastroenterology, University of Alberta, Zeidler Ledcor Centre, Edmonton, Alberta T6G 2 X8.

Telephone 780-492-6941, fax 780-492-8121, e-mail dloomes@ualberta.ca

Received for publication October 3, 2010. Accepted February 24, 2011 
TABLE 1

Patient demographics

\begin{tabular}{lcc}
\hline & \multicolumn{2}{c}{$\begin{array}{c}\text { Years before and } \\
\text { after infliximab }\end{array}$} \\
\cline { 2 - 3 } Characteristic & One (n=66) & Two (n=39) \\
\hline Female sex & $41(62.1)$ & $24(61.5)$ \\
Caucasian & $62(93.9)$ & $35(89.7)$ \\
Age at first infliximab infusion, years, mean \pm SD & $42.0 \pm 11.6$ & $43.2 \pm 11.6$ \\
Duration of Crohn's disease, years, mean \pm SD & $15.8 \pm 8.7$ & $17.5 \pm 8.7$ \\
Years between diagnosis and first infliximab & $10.1 \pm 8.1$ & $10.9 \pm 8.1$ \\
$\quad$ infusion, mean \pm SD & & \\
Disease location & $10(15.2)$ & $4(10.3)$ \\
$\quad$ lleum & $24(36.4)$ & $16(41.0)$ \\
$\quad$ Colon & $32(48.5)$ & $19(48.7)$ \\
lleum and colon & $6(9.1)$ & $3(7.7)$ \\
$\quad$ Gastroduodenal & & \\
Disease subtype & $31(47.0)$ & $20(51.3)$ \\
$\quad$ Luminal with fistula & $30(45.5)$ & $19(48.7)$ \\
$\quad$ Luminal without fistula & $7.4 \pm 1.4$ & $5.7 \pm 2.1$ \\
Infliximab infusions per year, mean \pm SD & $44(66.7)$ & $22(56.4)$ \\
Mean number of patients on infliximab at & \multicolumn{2}{|c}{} \\
$\quad$ end of study period & $20(64.5)$ & $12(60.0)$ \\
Luminal with fistula & $19(63.3)$ & $10(52.6)$ \\
\hline Luminal without fistula & & \\
\hline
\end{tabular}

Data presented as $n$ (\%) unless otherwise indicated

health region. Patients whose Crohn's disease responded to induction treatment with infliximab (loading doses at zero, two and six weeks) and who were followed for at least one year since the first infliximab infusion were included in the analysis. Clinical response to induction was defined according to the physician's global assessment 10 to 12 weeks after the first infliximab dose, as determined by the physician's documentation of significant and clinically relevant improvement in diarrhea, abdominal pain, extraintestinal symptoms and general well-being. This has previously been demonstrated to correlate closely with the Crohn's Disease Activity Index (20). From 160 patients identified in the Zeidler database, 74 patients fulfilled the inclusion criteria. Sixtysix patients had complete costing data one year pre- and postinitiation of infliximab; 39 of these patients had complete costing data two years preceding and following infliximab therapy. All patients served as their own controls in the analysis.

In all cases, infliximab use was in accordance with the Canadian Association of Gastroenterology guidelines for infliximab treatment in Crohn's disease (1). Patients who underwent previous treatment with other antitumour necrosis factor biological therapy for any indication, and who had a history of cancer with less than two years of documented disease-free state (other than resected cutaneous basal and squamous cell carcinoma or in situ cervical cancer) were excluded.

Retrospective analysis of patient charts was performed to gather baseline demographics. Disease subtype was not identified in five charts.

The primary end points were defined as direct resource use and health care costs before and after infliximab therapy. Health care resources and costs were divided into the following major categories: health care visit, endoscopy, radiology and therapeutic intervention; these categories were further subdivided into inpatient and outpatient services, and finally subdivided into various types of health care encounters. Some types of health care encounters were composed of multiple diagnoses or procedures. Nonsurgical management of inflammatory bowel disease (IBD)-related hospitalization was composed of management of IBD and of gastrointestinal obstruction. Minor surgeries were defined as less extensive esophageal, stomach and duodenal procedures, less extensive intestinal and rectal procedures, minor gastrointestinal procedures, abdominal laparoscopy, and anus and stomal procedures. Major surgeries were composed of major esophageal, stomach and duodenum procedures, major intestinal and rectal procedures, laparotomy, extensive gastrointestinal procedures, and gastrostomy and colostomy procedures.

Secondary outcomes were health care costs divided by the number of patients with Crohn's disease with fistulae or those without fistulae.

The inpatient costs in the current study, including direct patient care costs, administrative overhead, facility maintenance and other nonpatient care costs as measured by Case Mix Groups (CMG) and complexity modifier codes associated with each hospitalization, were derived from the Alberta Health and Wellness 2006 Annual Report, Health Costing In Alberta (21). Doctors' fees were calculated using the provincial fee schedule (22). Service categories were extrapolated from the Canadian Classification of Health Interventions codes that were included in each patient's hospital encounter information. There were no costs calculated for inpatient endoscopy and radiology because these were encompassed by the CMG code costs. Outpatient services included diagnostic tests, procedures and visits, but excluded costs of medications other than infliximab, as well as nonpatient care costs. Outpatient costs were extracted from the Ambulatory Care Classification System provincial costing database (21), which contains direct costs for each procedure and visit type, and were added to the corresponding doctors' fees. The cost of infliximab was calculated using the median patient dose of $400 \mathrm{mg}$, and a supplier cost of CAD\$3,152 per $400 \mathrm{mg}$ (Canadian supplier cost at August 2010). All costs in the tables have been standardized to 2005 United States dollars $(23,24)$. The total number of infliximab doses were determined by a retrospective review of each patient's infusion records.

Statistical analysis was performed using the statistical software programs Stata/MP 11 (StataCorp LP, USA). Primary and secondary outcome analyses were compared using a paired $t$ test. Demographics were analyzed by descriptive methods, and $\mathrm{P}<0.05$ was considered to be statistically significant.

\section{Patient demographics}

\section{RESULTS}

The demographic characteristics of the patient population are summarized in Table 1 . In the analysis of 66 patients who had available economic data one year before and after infliximab, $62.1 \%$ of the study population were women and $93.9 \%$ were Caucasian. The mean $( \pm$ SD) age at the time of the first infliximab infusion was $42.0 \pm 11.6$ years. Length of time between diagnosis and first infusion of infliximab, and overall duration of Crohn's disease was $10.1 \pm 8.1$ years and $15.8 \pm 8.7$ years, respectively. The majority of patients had ileocecal $(48.5 \%)$, colonic $(36.4 \%)$ or ileal $(15.2 \%)$ disease. The percentage of patients with fistulizing disease (47.0\%) and nonfistulizing disease (45.5\%) were comparable (note: in five records, it was not possible to confirm the presence or absence of fistulizing disease). Patients analyzed according to either one year or two years before and after infliximab were similar in all characteristics, with the exception of the mean percentage of patients on infliximab at the end of the study period (66.7\% versus $56.4 \%)$, and the mean number of infliximab infusions per year ( $7.4 \pm 1.4$ infusions versus $5.7 \pm 2.1$ infusions). In the subgroup analysis of patients with or without fistulizing disease one year before and after infliximab, there was no difference in infliximab use $(64.5 \%$ and $63.3 \%$, respectively).

\section{Health care resource use before and after infliximab use}

Total health care resource use one year and two years before and after infliximab therapy were compared (Table 2).

One-year analysis: There were significant decreases in total hospital days (495 to $155[\mathrm{P}<0.05]$ ), inpatient colonoscopies (46 to $24[\mathrm{P}<0.05]$ ), outpatient colonoscopies ( 58 to $33[\mathrm{P}<0.05]$ ) and major surgeries ( 10 to $2[\mathrm{P}<0.05])$ in the year following infliximab therapy. Reductions in hospitalizations $(-22[\mathrm{P}=0.06])$, emergency room visits $(-23[\mathrm{P}=0.12])$, admissions for nonsurgical management of IBD-related illness $(-11$ $[\mathrm{P}=0.10])$ and day surgeries $(-7[\mathrm{P}=0.11])$ all approached but did not 
TABLE 2

Total health care resource use one year and two years before (B) and after (A) infliximab (IFX)

\begin{tabular}{|c|c|c|c|c|c|c|c|c|}
\hline \multirow[b]{2}{*}{ Resource } & \multicolumn{4}{|c|}{ One year before and after IFX } & \multicolumn{4}{|c|}{ Two years before and after IFX } \\
\hline & B-IFX & A-IFX & Reduction & $\begin{array}{c}\mathrm{P} \\
(t \text { test })\end{array}$ & B-IFX & A-IFX & Reduction & $\begin{array}{c}P \\
(t \text { test })\end{array}$ \\
\hline \multicolumn{9}{|l|}{ Health care visit } \\
\hline \multicolumn{9}{|l|}{ Inpatient } \\
\hline Hospitalization & 47 & 25 & 22 & 0.06 & 26 & 14.5 & 11.5 & 0.14 \\
\hline Hospital day & 495 & 155 & -340 & $<0.05$ & 346 & 160 & -186 & 0.10 \\
\hline \multicolumn{9}{|l|}{ Outpatient } \\
\hline Emergency room visit & 52 & 29 & -23 & 0.12 & 38 & 42 & 4 & 0.79 \\
\hline Outpatient visit & 182 & 205 & 23 & $<0.05$ & 199 & 275 & 76 & $<0.05$ \\
\hline \multicolumn{9}{|l|}{ Endoscopy } \\
\hline \multicolumn{9}{|l|}{ Inpatient } \\
\hline Esophagogastroduodenoscopy & 18 & 20 & 2 & 0.78 & 17 & 21 & 4 & 0.60 \\
\hline Colonoscopy & 46 & 24 & -22 & $<0.05$ & 26 & 41 & 15 & 0.34 \\
\hline \multicolumn{9}{|l|}{ Outpatient } \\
\hline Esophagogastroduodenoscopy & 1 & 0 & -1 & 0.32 & 0 & 0 & 0 & NA \\
\hline Colonoscopy & 58 & 33 & -25 & $<0.05$ & 68 & 41 & -27 & 0.16 \\
\hline \multicolumn{9}{|l|}{ Radiology } \\
\hline \multicolumn{9}{|l|}{ Inpatient } \\
\hline Computed tomography scan & 19 & 10 & -9 & 0.29 & 9 & 12 & 3 & 0.62 \\
\hline Magnetic resonance imaging & 0 & 1 & 1 & 0.32 & 3 & 1 & -2 & 0.53 \\
\hline Other x-ray & 24 & 13 & -11 & 0.29 & 20 & 19 & -1 & 0.94 \\
\hline \multicolumn{9}{|l|}{ Outpatient } \\
\hline Computed tomography scan & 16 & 11 & -5 & 0.36 & 16 & 12 & -4 & 0.50 \\
\hline Magnetic resonance imaging & 5 & 7 & 2 & 0.58 & 7 & 5 & -2 & 0.60 \\
\hline Other x-ray & 5 & 4 & -1 & 0.78 & 8 & 4 & -4 & 0.42 \\
\hline \multicolumn{9}{|l|}{ Therapeutic intervention } \\
\hline \multicolumn{9}{|l|}{ Inpatient } \\
\hline Nonsurgical management & 22 & 11 & -11 & 0.10 & 19 & 13 & -6 & 0.45 \\
\hline Minor surgery & 3 & 3 & 0 & 1.00 & 6 & 3 & -3 & 0.49 \\
\hline Major surgery & 10 & 2 & -8 & $<0.05$ & 12 & 3 & -9 & $<0.05$ \\
\hline \multicolumn{9}{|l|}{ Outpatient } \\
\hline Day surgery & 12 & 5 & -7 & 0.11 & 16 & 9 & -7 & 0.20 \\
\hline Transfusion & 7 & 5 & -2 & 0.71 & 7 & 3 & -4 & 0.59 \\
\hline
\end{tabular}

Data presented as total, n. NA Not available

reach the threshold of statistical significance. Total outpatient visits increased (182 to $205[\mathrm{P}<0.05])$ following induction therapy, probably as a consequence of the infliximab infusion visits.

Two-year analysis: In general, trends of resource use analyzed over four consecutive years (two-year analysis) paralleled the one-year analysis. In the two-year analysis of resource use, major surgeries also decreased pre- and post-infliximab (12 per year to three per year $[\mathrm{P}<0.05])$; outpatient visits increased $(199$ per year to 275 per year $[\mathrm{P}<0.05])$.

Comparison of health care costs before and after infliximab therapy

Health care costs per patient one year and two years before and after infliximab therapy were compared (Table 3).

One-year analysis: There was a reduction in total combined inpatient and outpatient costs $(-\$ 1,912[\mathrm{P}<0.05])$, with the majority being attributed to inpatient costs $(-\$ 1,747[\mathrm{P}<0.05])$ in the year following initiation of infliximab therapy compared with the preceding year. Health care expenditures on major surgeries also fell $(-\$ 1,240$ $[\mathrm{P}<0.05])$, as did the cost of outpatient colonoscopies $(-\$ 184[\mathrm{P}<0.05])$ following treatment with infliximab. A downward trend in nonsurgical management of IBD-related hospitalization $(-\$ 546[\mathrm{P}=0.05])$ nearly reached statistical significance. A small rise was seen in outpatient visit costs per patient $(\$ 193[\mathrm{P}<0.05])$, although total outpatient costs trended down $(-\$ 165[\mathrm{P}=0.30])$. With the cost of induction and maintenance infliximab added to the reduced total combined inpatient and outpatient costs, total direct health care costs increased $(\$ 21,416[\mathrm{P}<0.05])$.

Two-year analysis: In patients who had four consecutive years of economic data available, analysis of costing per patient pre- and post-infliximab therapy revealed a trend toward reduction in total combined inpatient and outpatient costs $(-\$ 1,852[\mathrm{P}=0.08])$, with the majority of this reduction being attributed to inpatient costs $(-\$ 1,844$ $[\mathrm{P}=0.06])$. Health care costs related to major surgeries also fell $(-\$ 1,545[\mathrm{P}=0.05])$ with two years of infliximab maintenance infusions, despite a decrease in infliximab use from $66.7 \%$ to $56.4 \%$ from the first year to the second year after induction (Table 1$)$. There was an increase in outpatient visit costs $(\$ 233[\mathrm{P}<0.05])$, but total outpatient costs did not change significantly $(-\$ 8[\mathrm{P}=0.97])$. With the cost of maintenance infliximab added to the reduced total combined inpatient and outpatient costs, total direct costs trended up in the twoyear analysis $(\$ 16,117[\mathrm{P}=0.08])$, although the cost per patient per year was lower than in the one-year before and after analysis.

Costs according to luminal or fistulizing disease subtype

Health care expenditures per patient were stratified according to the presence or absence of fistulizing disease (Table 4). The use of infliximab resulted in significant reductions in combined inpatient and outpatient costs $(-\$ 3,162[\mathrm{P}<0.05])$ as well as inpatient costs $(-\$ 2,530$ $[\mathrm{P}<0.05])$ in patients with fistulizing disease, but not in patients 
TABLE 3

Health care costs per patient one year and two years before (B) and after (A) infliximab (IFX) therapy

\begin{tabular}{|c|c|c|c|c|c|c|c|c|}
\hline \multirow[b]{2}{*}{ Resource } & \multicolumn{4}{|c|}{ One year before and after IFX } & \multicolumn{4}{|c|}{ Two years before and after IFX } \\
\hline & $\begin{array}{l}\text { B-IFX, } \\
\text { mean }\end{array}$ & $\begin{array}{l}\text { A-IFX, } \\
\text { mean }\end{array}$ & $\begin{array}{c}\text { Reduction } \\
\text { (difference) }\end{array}$ & $\begin{array}{c}\mathrm{P} \\
(t \text { test) }\end{array}$ & $\begin{array}{l}\text { B-IFX, } \\
\text { mean }\end{array}$ & $\begin{array}{l}\text { A-IFX, } \\
\text { mean }\end{array}$ & $\begin{array}{l}\text { Reduction } \\
\text { (difference) }\end{array}$ & $\begin{array}{c}\mathrm{P} \\
(t \text { test })\end{array}$ \\
\hline \multicolumn{9}{|l|}{ Health care visit } \\
\hline \multicolumn{9}{|l|}{ Inpatient } \\
\hline Hospitalization & 2,715 & 968 & $-1,747$ & $<0.05$ & 2,881 & 1,037 & $-1,844$ & 0.06 \\
\hline \multicolumn{9}{|l|}{ Outpatient } \\
\hline Emergency room visit & 191 & 107 & -85 & 0.12 & 118 & 131 & 12 & 0.79 \\
\hline Outpatient visit & 285 & 478 & 193 & $<0.05$ & 264 & 497 & 233 & $<0.05$ \\
\hline \multicolumn{9}{|l|}{ Endoscopy } \\
\hline \multicolumn{9}{|l|}{ Inpatient } \\
\hline Esophagogastroduodenoscopy & - & - & - & - & - & - & - & - \\
\hline Colonoscopy & - & - & - & - & - & - & - & - \\
\hline \multicolumn{9}{|l|}{ Outpatient } \\
\hline Esophagogastroduodenoscopy & 6 & 0 & -6 & 0.32 & 0 & 0 & 0 & \\
\hline Colonoscopy & 426 & 242 & -184 & $<0.05$ & 423 & 255 & -168 & 0.16 \\
\hline \multicolumn{9}{|l|}{ Radiology } \\
\hline \multicolumn{9}{|l|}{ Inpatient } \\
\hline Computed tomography scan & - & - & - & - & - & - & - & - \\
\hline Magnetic resonance imaging & - & - & - & - & - & - & - & - \\
\hline Other x-ray & - & - & - & - & - & - & - & - \\
\hline \multicolumn{9}{|l|}{ Outpatient } \\
\hline Computed tomography scan & 114 & 75 & -39 & 0.32 & 99 & 72 & -27 & 0.47 \\
\hline Magnetic resonance imaging & 38 & 53 & 15 & 0.58 & 45 & 32 & -13 & 0.59 \\
\hline Other x-ray & 10 & 8 & -2 & 0.78 & 14 & 7 & -7 & 0.42 \\
\hline \multicolumn{9}{|l|}{ Therapeutic intervention } \\
\hline \multicolumn{9}{|l|}{ Inpatient } \\
\hline Nonsurgical management & 926 & 380 & -546 & 0.05 & 728 & 375 & -353 & 0.22 \\
\hline Minor surgery & 113 & 217 & 104 & 0.57 & 160 & 184 & 24 & 0.89 \\
\hline Major surgery & 1,504 & 263 & $-1,240$ & $<0.05$ & 1,895 & 351 & $-1,545$ & 0.05 \\
\hline \multicolumn{9}{|l|}{ Outpatient } \\
\hline Day surgery & 110 & 62 & -47 & 0.36 & 108 & 86 & -22 & 0.67 \\
\hline Transfusion & 36 & 26 & -10 & 0.71 & 30 & 13 & -17 & 0.59 \\
\hline \multicolumn{9}{|l|}{ Total cost } \\
\hline Inpatient & 2,715 & 968 & $-1,747$ & $<0.05$ & 2,881 & 1,037 & $-1,844$ & 0.06 \\
\hline Outpatient & 1,216 & 1,051 & -165 & 0.30 & 1,101 & 1,093 & -8 & 0.97 \\
\hline Combined inpatient and outpatient & 3,930 & 2,018 & $-1,912$ & $<0.05$ & 3,981 & 2,129 & $-1,852$ & 0.08 \\
\hline Infliximab & 0 & 23,328 & 23,328 & - & 0 & 17,969 & 17,969 & - \\
\hline Total direct & 3,930 & 25,346 & 21,416 & $<0.05$ & 3,981 & 20,098 & 16,117 & 0.08 \\
\hline
\end{tabular}

Data presented as \$

without fistulizing disease $(-\$ 1,397[\mathrm{P}=0.30]$ and $-\$ 1,196[\mathrm{P}=0.29]$, respectively). A difference in the costs of nonsurgical management of IBD-related hospitalizations in patients with fistulae versus without fistulae was also noted $(-\$ 1,111[\mathrm{P}<0.05]$ and $-\$ 52[\mathrm{P}=0.90]$, respectively). Both fistulizing and nonfistulizing subgroups had a trend toward decreased cost of major surgeries $(-\$ 1,569[\mathrm{P}=0.10]$ and $-\$ 1,788$ $[\mathrm{P}=0.08]$, respectively). The difference between total direct cost for patients with fistulae pre- and post-infliximab and without fistulae was nonsignificant $(\$ 20,787$ versus $\$ 20,591$, respectively $[P=0.44])$.

\section{DISCUSSION}

Infliximab is a mainstay of therapy for moderate to severe Crohn's disease due to its superior efficacy in the treatment of luminal (4) and fistulizing (5) disease over traditional therapies such as corticosteroids and immunosuppressive medications. However, despite this widespread use, the overall impact on health-related expenditures is unclear.

The results of the present study demonstrated a reduction in inpatient resource use and costs with infliximab therapy. This reduction may extend into the second year of treatment, despite an overall decrease in infliximab use over this time. The present analysis suggests, as do other similar studies $(13,25)$, that this reduction in inpatient costs is largely driven by a decrease in hospitalizations, colonoscopies and surgeries. When the cost of infliximab is factored into the analysis, there was a net increase in overall direct costs, similar to the findings of Saro et al (17). However, in countries with a higher cost structure, such as the United States, a combined reduction of inpatient and outpatient costs by almost 50\% after two years of treatment may very well translate into an overall cost savings with infliximab therapy.

The magnitude of health care cost savings in patients with fistulizing disease may be greater than for those without fistulizing disease. A greater decrease in hospitalizations and surgical interventions in patients with fistulizing disease has been previously suggested (15). In the present analysis, the decrease in combined inpatient and outpatient costs was only significant for patients with fistulizing disease, although combined costs did trend downward in the nonfistulizing subgroup. Both subgroups of patients showed similar downward trends in major surgeries. A recent study by Taxonera et al (26) did not demonstrate a difference in hospitalizations or surgeries between fistulizing and nonfistulizing subgroups. 
TABLE 4

Health care costs per patient stratified according to the presence or absence of fistulizing disease

\begin{tabular}{|c|c|c|c|c|c|c|c|c|c|}
\hline \multirow[b]{2}{*}{ Resource } & \multicolumn{4}{|c|}{ Luminal disease with fistulae } & \multicolumn{4}{|c|}{ Luminal disease without fistulae } & \multirow{2}{*}{$\begin{array}{c}\text { Difference } \\
P \\
(t \text { test })\end{array}$} \\
\hline & $\begin{array}{l}\text { B-IFX, } \\
\text { mean }\end{array}$ & $\begin{array}{l}\text { A-IFX, } \\
\text { mean }\end{array}$ & $\begin{array}{l}\text { Reduction } \\
\text { (difference) }\end{array}$ & $\begin{array}{c}\mathrm{P} \\
(t \text { test) }\end{array}$ & $\begin{array}{l}\text { B-IFX, } \\
\text { mean }\end{array}$ & $\begin{array}{l}\text { A-IFX, } \\
\text { mean }\end{array}$ & $\begin{array}{c}\text { Reduction } \\
\text { (difference) }\end{array}$ & $\begin{array}{c}\mathrm{P} \\
(t \text { test) }\end{array}$ & \\
\hline \multicolumn{10}{|l|}{ Health care visit } \\
\hline \multicolumn{10}{|l|}{ Inpatient } \\
\hline Hospitalization & 3,074 & 544 & $-2,530$ & $<0.05$ & 2,756 & 1,559 & $-1,196$ & 0.29 & 0.35 \\
\hline \multicolumn{10}{|l|}{ Outpatient } \\
\hline Emergency room visit & 94 & 78 & -16 & 0.79 & 267 & 146 & -121 & 0.21 & 0.1 \\
\hline Outpatient visit & 277 & 587 & 310 & $<0.01$ & 331 & 441 & 110 & 0.45 & 0.09 \\
\hline \multicolumn{10}{|l|}{ Endoscopy } \\
\hline \multicolumn{10}{|l|}{ Inpatient } \\
\hline Esophagogastroduodenoscopy & - & - & - & - & - & - & - & - & - \\
\hline Colonoscopy & - & - & - & - & - & - & - & - & - \\
\hline \multicolumn{10}{|l|}{ Outpatient } \\
\hline Esophagogastroduodenoscopy & 0 & 0 & 0 & NA & 14 & 0 & -14 & 0.32 & 0.31 \\
\hline Colonoscopy & 375 & 250 & -125 & 0.29 & 453 & 275 & -178 & 0.14 & 0.66 \\
\hline \multicolumn{10}{|l|}{ Radiology } \\
\hline \multicolumn{10}{|l|}{ Inpatient } \\
\hline Computed tomography scan & - & - & - & - & - & - & - & - & - \\
\hline Magnetic resonance imaging & - & - & - & - & - & - & - & - & - \\
\hline Other x-ray & - & - & - & - & - & - & - & - & - \\
\hline \multicolumn{10}{|l|}{ Outpatient } \\
\hline Computed tomography scan & 76 & 58 & -18 & 0.71 & 143 & 90 & -53 & 0.43 & 0.63 \\
\hline Magnetic resonance imaging & 65 & 49 & -16 & 0.7 & 17 & 50 & 33 & 0.41 & 0.37 \\
\hline Other x-ray & 13 & 0 & -13 & 0.08 & 9 & 18 & 9 & 0.52 & $<0.05$ \\
\hline \multicolumn{10}{|l|}{ Therapeutic intervention } \\
\hline \multicolumn{10}{|l|}{ Inpatient } \\
\hline \multicolumn{10}{|l|}{ Nonsurgical } \\
\hline Management & 1,189 & 77 & $-1,111$ & $<0.05$ & 808 & 756 & -52 & 0.9 & 0.05 \\
\hline Minor surgery & 240 & 154 & -86 & 0.73 & 0 & 318 & 318 & 0.32 & 0.32 \\
\hline Major surgery & 1,478 & 223 & -1256 & 0.1 & 1,781 & 350 & -1431 & 0.08 & 0.87 \\
\hline \multicolumn{10}{|l|}{ Outpatient } \\
\hline Day surgery & 208 & 117 & -91 & 0.39 & 27 & 17 & -10 & 0.7 & 0.38 \\
\hline Transfusion & 43 & 0 & -43 & 0.32 & 34 & 56 & 22 & 0.59 & 0.25 \\
\hline \multicolumn{10}{|l|}{ Total costs } \\
\hline Inpatient & 3,074 & 544 & $-2,530$ & $<0.05$ & 2,756 & 1,559 & $-1,196$ & 0.29 & 0.35 \\
\hline Outpatient & 1,151 & 1,139 & -12 & 0.96 & 1,293 & 1,092 & -201 & 0.45 & 0.49 \\
\hline $\begin{array}{l}\text { Combined inpatient and } \\
\text { outpatient }\end{array}$ & 4,224 & 1,683 & $-2,542$ & $<0.05$ & 4,049 & 2,651 & $-1,397$ & 0.28 & 0.44 \\
\hline Infliximab & 0 & 23,328 & 23,328 & - & 0 & 27,820 & 27,820 & - & - \\
\hline Total direct & 4,224 & 25,011 & 20,787 & $<0.05$ & 4,049 & 24,640 & 20,591 & 0.28 & 0.44 \\
\hline
\end{tabular}

Data presented as \$. A-IFX After infliximab; B-IFX Before infliximab; NA Not available

It is recognized that the present study was limited by its retrospective design and the lack of a traditional control group. However, given that the population studied was considered to be a representative sample and that infliximab is now of proven benefit for patients with Crohn's disease, using a control group would be neither ethical nor reasonable. The absence of outpatient drug costing data potentially limited some additional savings with infliximab. Although infliximab is recognized to be corticosteroid sparing in approximately one-third of patients (4), overall, the cost of corticosteroids are relatively low compared with the other direct costs involved. Infliximab use is not expected to result in cost savings of immunosuppressives as evidenced by the Study of Biologic and Immunomodulator Naive Pateints in Crohn's disease (SONIC) trial (27).

The current study only included responders to infliximab in the analysis because its objective was to examine patient costs before and after therapy. Patients excluded from the present analysis comprised a heterogenous group of patients who did not tolerate infliximab infusions or did not respond to induction therapy. The economic implications of including patients with a lack of response to infliximab or those that do not tolerate infliximab will lead to higher associated economic costs.

Perhaps the greatest limitation of the majority of economic studies to date is the lack of indirect costing data. Concessions made in career choices, disability compensation, early retirement and unemployment are all indirect costs to society that are difficult to quantify, but have been estimated to be responsible for $68 \%$ of overall health care expenditures (8). Crohn's disease is associated with a significantly decreased quality of life (28), and induction and maintenance of remission has been demonstrated to increase employment and normalize quality of life $(16,29)$. Thus, the present analysis likely underestimated the true financial burden of Crohn's disease. Additional studies regarding the indirect costs of Crohn's disease are needed to elucidate the impact of infliximab on overall cost effectiveness. 


\section{CONCLUSION}

Infliximab therapy in patients with Crohn's disease resulted in a significant decrease in resource use and costs, reflected in decreases in hospital days, colonoscopies, surgeries and total inpatient costs. Nevertheless, an increase in total direct health care costs was observed once the cost of infliximab was added.

ACKNOWLEDGEMENT: Centre of Excellence for Gastrointestinal Inflammation and Immunity Research (Edmonton, Alberta).

\section{REFERENCES}

1. Sadowski DC, Bernstein CN, Bitton A, et al. Canadian Association of Gastroenterology Clinical Practice Guidelines: The use of tumour necrosis factor-alpha antagonist therapy in Crohn's disease. Can J Gastroenterol 2009;23:185-202.

2. Present DH, Rutgeerts P, Targan S, et al. Infliximab for the treatment of fistulas in patients with Crohn's disease. N Engl J Med 1999;340:1398-405.

3. Targan SR, Hanauer SB, van Deventer SJ, et al. A short-term study of chimeric monoclonal antibody cA2 to tumor necrosis factor alpha for Crohn's disease. Crohn's Disease cA2 Study Group. N Engl J Med 1997;337:1029-35.

4. Hanauer SB, Feagan BG, Lichtenstein GR, et al. Maintenance infliximab for Crohn's disease: The ACCENT I randomised trial. Lancet 2002;359:1541-9.

5. Sands BE, Anderson FH, Bernstein CN, et al. Infliximab maintenance therapy for fistulizing Crohn's disease. N Engl J Med 2004:350:876-85.

6. Koelewijn C, Schrijvers A, Oldenburg B. Infliximab use in patients with Crohn's disease: Quality of life, costs and resource use. Netherlands J Med 2006;64:212-8.

7. Bernstein CN, Wajda A, Svenson LW, et al. The epidemiology of inflammatory bowel disease in Canada: A population-based study. Am J Gastroenterol 2006;101:1559-68.

8. Blomqvist P, Ekbom A. Inflammatory bowel diseases: Health care and costs in Sweden in 1994. Scand J Gastroenterol 1997;32:1134-9.

9. Feagan BG, Vreeland MG, Larson LR, Bala MV. Annual cost of care for Crohn's disease: A payor perspective. Am J Gastroenterology 2000;95:1955-60.

10. Hay JW, Hay AR. Inflammatory bowel disease: Costs-of-illness. J Clin Gastroenterol 1992;14:309-17.

11. Bernstein CN, Papineau N, Zajaczkowski J, Rawsthorne P, Okrusko G, Blanchard JF. Direct hospital costs for patients with inflammatory bowel disease in a Canadian tertiary care university hospital. Am J Gastroenterol 2000;95:677-83.

12. Cohen RD, Larson LR, Roth JM, Becker RV, Mummert LL. The cost of hospitalization in Crohn's disease. Am J Gastroenterol 2000;95:524-30.
13. Jewell DP, Satsangi J, Lobo A, et al. Infliximab use in Crohn's disease: Impact on health care resources in the UK. Eur J Gastroenterol Heaptol 2005;17:1047-52.

14. Lichtenstein GR, Yan S, Bala M, Blank M, Sands BE. Infliximab maintenance treatment reduces hospitalizations, surgeries, and procedures in fistulizing Crohn's disease. Gastroenterology 2005;128:862-9.

15. Rubenstein JH, Chong RY, Cohen RD. Infliximab decreases resource use among patients with Crohn's disease. J Clin Gastroenterol 2002;35:151-6.

16. Rutgeerts P, Feagan BG, Lichtenstein GR, et al. Comparison of scheduled and episodic treatment strategies of infliximab in Crohn's disease. Gastroenterology 2004;126:402-13.

17. Saro C, De La Coba C, Casado M, Morales J, Otero B. Resource use in patients with Crohn's disease treated with infliximab. Aliment Pharmacol Thera 2007;26:1313-23.

18. Wu EQ, Mulani PM, Yu AP, Tang J, Pollack PF. Loss of treatment response to infliximab maintenance therapy in Crohn's disease: A payor perspective. Value in health. J Int Soc Pharmacoecon and Outcomes Res 2008;11:820-9.

19. Cohen RD, Thomas T. Economics of the use of biologics in the treatment of inflammatory bowel disease. Gastroenterol Clin North Am 2006;35:867-82.

20. Teshima CW, Thompson A, Dhanoa L, Dieleman LA, Fedorak RN. Long-term response rates to infliximab therapy for Crohn's disease in an outpatient cohort. Can J Gastroenterol 2009;23:348-52.

21. Health Authority Funding and Financial Accountability. Health Costing in Alberta. Annual Report. Edmonton: Alberta Health and Wellness, 2006.

22. Alberta Health Care Insurance Plan. Medical Procedure List. Schedule of Medical Benefits. Edmonton: Alberta Health and Wellness, 2006.

23. Statistics Canada. Consumer price indexes for Canada, monthly. <www.bankofcanada.ca/en/rates/inflation_calc.html> (Accessed on May 30, 2010).

24. XE Currency Conversion Chart. <www.xe.com/currencycharts/> (Accessed on May 30, 2010)

25. Sprakes MB, Ford AC, Suares NC, et al. Costs of care for Crohn's disease following the introduction of infliximab: A single-centre UK experience. Aliment Pharmacol Ther 2010;32:1357-63.

26. Taxonera C, Rodrigo L, Casellas F, et al. Infliximab maintenance therapy is associated with decreases in direct resource use in patients with luminal or fistulizing Crohn's disease. J Clin Gastroenterol 2009;43:950-6.

27. Colombel JF, Sandborn WJ, Reinisch W, et al. Infliximab, azathioprine, or combination therapy for Crohn's disease. N Engl J Med 2010;362:1383-95.

28. Feagan BG, Yan S, Bala M, Bao W, Lichtenstein GR. The effects of infliximab maintenance therapy on health-related quality of life. Am J Gastroenterol 2003;98:2232-8.

29. Lichtenstein GR, Yan S, Bala M, Hanauer S. Remission in patients with Crohn's disease is associated with improvement in employment and quality of life and a decrease in hospitalizations and surgeries. Am J Gastroenterol 2004;99:91-6. 


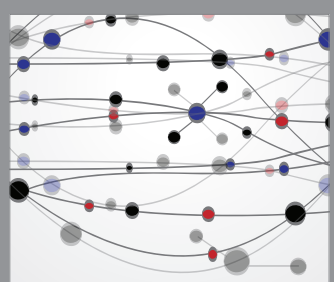

The Scientific World Journal
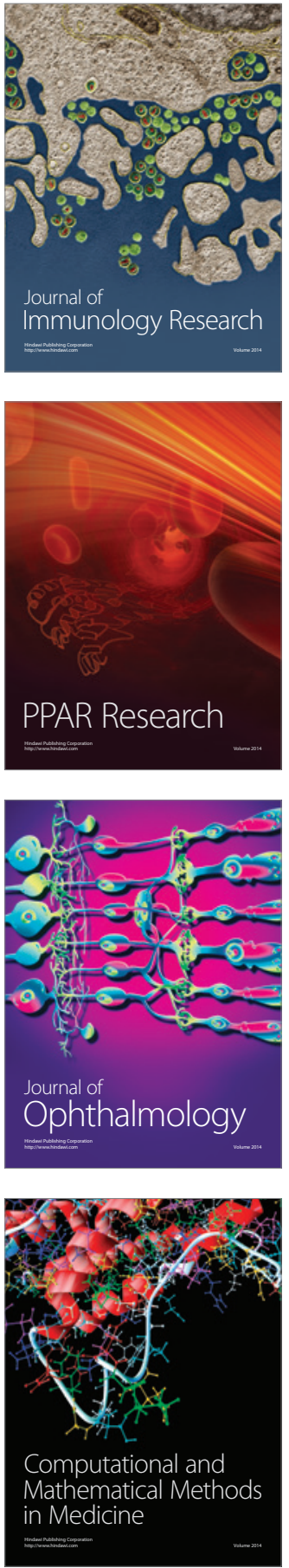

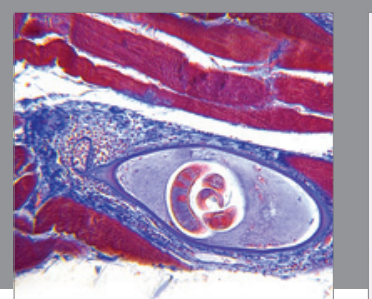

Gastroenterology Research and Practice

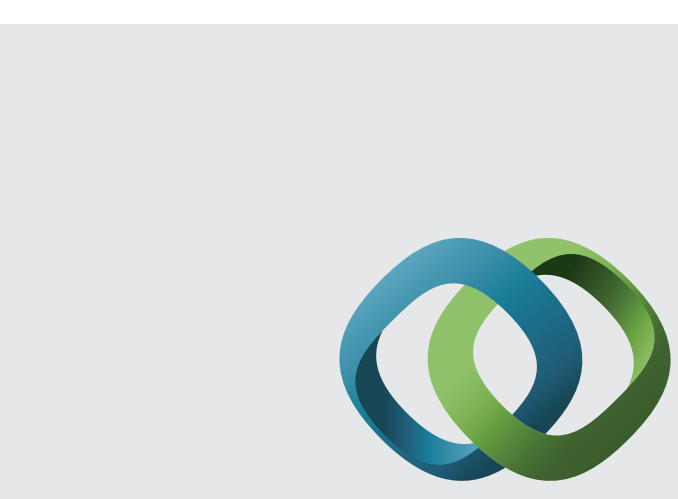

\section{Hindawi}

Submit your manuscripts at

http://www.hindawi.com
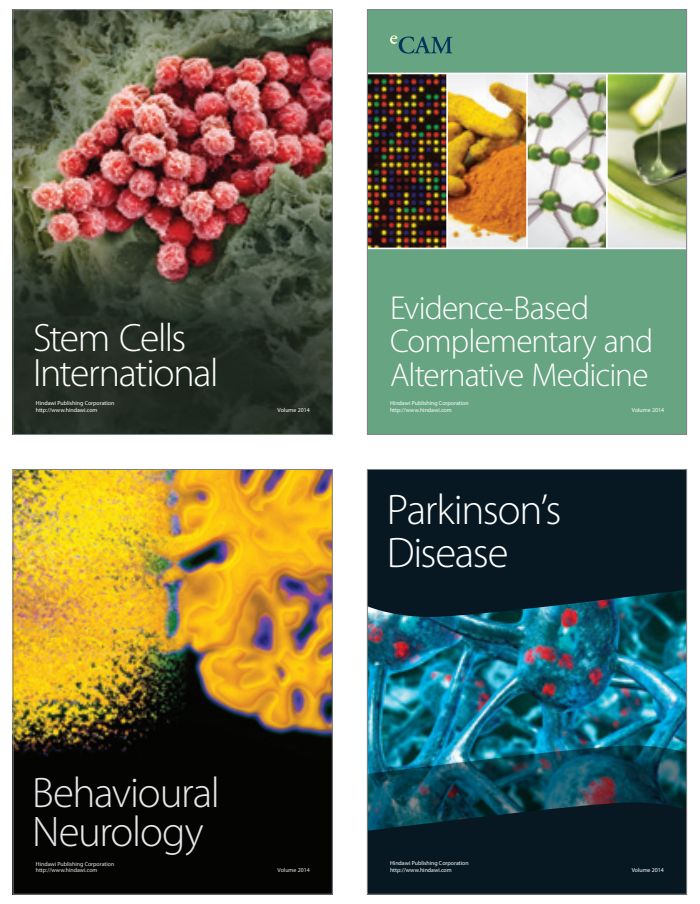
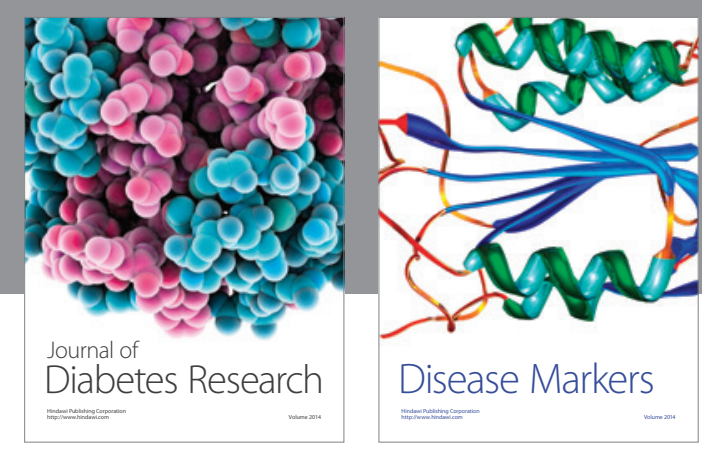

Disease Markers
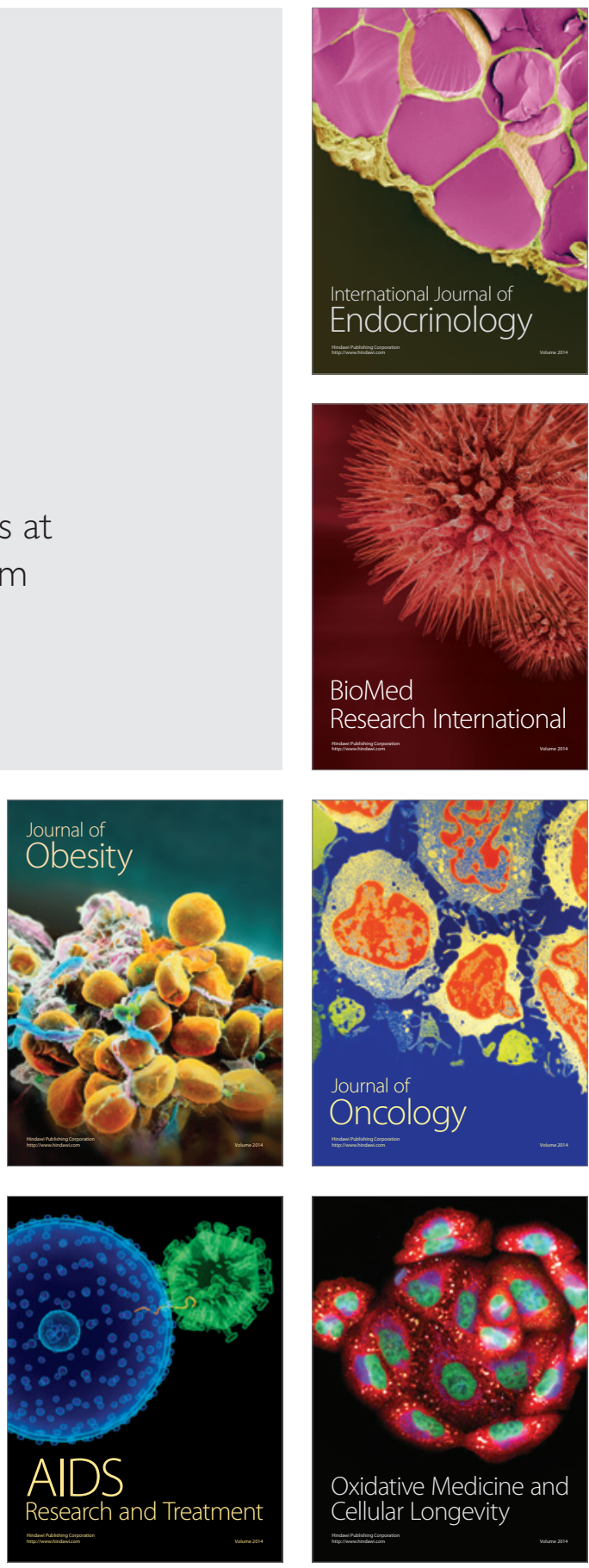